\title{
Energy Intensity: \\ Prices, Policy, or Composition in US States
}

\author{
Arik Levinson \\ Georgetown University and NBER \\ arik.levinson@georgetown.edu
}

November 14, 2016

\begin{abstract}
This paper uses the historical experience of US states to consider why energy intensity has declined in some places more than in others, and whether that difference can help guide other states and countries in pursuing less energy-intensive (and therefore less pollution-intensive) economic growth. The variation in energy intensity across US states has been similar to the changes across countries, and some states - notably California - have been held up as models for the rest of the world by international organizations, such as the World Bank. I show that aggregate US energy intensity fell by 40 percent between 1982 and 2007, and that the decline is not explained by the decreasing industrial share of the US economy or the changing composition of the industrial sector. Across US states, prices and policies are correlated with the decreasing share and composition of manufacturing but not with the technology, or "technique," of production, which appears to be the most important source of US energy intensity gains. Importantly, energy intensity has been declining the most in states where economic growth has been the strongest.

\section{Acknowledgments}

This paper was prepared as part of the Value Added in Motion (VAM) project funded by the Enel Foundation. I am grateful to the Foundation for financial support, to Asif Islam for help with state expenditure data, to Jonah Birnberg and Julia Kieserman for research assistance, and to Claire Brunel for helpful discussions.
\end{abstract}




\section{Energy Intensity: Prices, Policy, or Composition in US States}

Energy consumption per dollar of GDP - energy intensity - has declined worldwide by 35 percent in the past 30 years. But that global average masks tremendous heterogeneity. In more than one-fifth of the world's countries, energy intensity increased. To reduce global greenhouse gas emissions without reversing economic growth, we must understand how some jurisdictions have been able to reduce their economies' energy intensities. Likely explanations include regulations, energy prices, and industrial composition. And each explanation comes with a different set of policy implications. If regulations explain the reduction, that suggests energy policies have worked as intended, without sacrificing economic growth, relative to jurisdictions that have become more energy intensive. If prices explain the reduction, that supports marketbased policies, such as taxes on energy-intensive industries commensurate with the external costs those industries generate. And if industrial composition explains the reductions in energy intensity, that raises the concern that the differences may involve no more than simply shifting energy around from one jurisdiction to another, without necessarily reducing overall energy use or pollution.

Figure 1 plots energy intensity for various parts of the world, indexed so that 1980 equals 100. Global energy per dollar of GDP fell by 25 percent, but as noted, that masks enormous diversity. Energy intensity grew by 86 percent in the Middle East, for example, but fell by 76 percent in China, 37 percent in the European Union, and 47 percent in the United States. Figure 2 plots the same concept across US states, revealing a similar diversity. Energy intensity grew by 46 percent in Alaska but fell by 69 percent in Oregon.

What accounts for this heterogeneity, and have government policies had any effect? To address these questions, I study the historical experience of US states during the 25-year period from 1982 to $2007 .{ }^{1}$ There are several advantages to studying states. US energy intensity has fallen even faster than that for the world, the changes in energy intensity across states have been similar to the changes across countries, and some states - notably California - have been held up

\footnotetext{
${ }^{1}$ I focus on the 25-year period from 1982 to 2007 because the US Census of Manufactures is conducted every five years, in years ending in two and seven.
} 
as models for the rest of the world by international organizations, such as the World Bank. More importantly, in the United States, industry composition can be studied at a highly disaggregated level. The 473 six-digit NAICS codes in the manufacturing sector are measured comparably across US states, ameliorating concerns about industry definition or aggregation bias. And finally, some states are comparable in size to large countries. If California, Texas, New York, and Florida were independent countries, they would rank among the world's top 20 largest economies. What happens in US states matters not just for local and US national policy but for the climate across the globe.

The rest of the paper is divided into three parts. First, I explore as a potential explanation for the decline in energy intensity the fact that manufacturing and other industrial sectors have played a diminishing role in the US economy over time. Nevertheless, that explains only a small part of the decline in US energy intensity. Most of the decline has occurred within sectors, and manufacturing deserves special focus as a large, energy-intensive, and geographically mobile sector. So in the second part of the paper, I look within the manufacturing sector and ask how much of its declining energy intensity is explained by the changing composition of manufacturing - that is, I ask whether the United States is producing relatively more goods whose production is less energy intensive. I show that composition changes do not account for the declining energy intensity of US manufacturing. Most of the decline, then, must be due to "technique" - changes in production processes and technologies that allow narrowly defined industries to produce more output with less energy. Finally, in the third part of the paper I examine how these explanations (declining manufacturing, changing composition, improved technique) differ across US states and see whether those differences are correlated systematically with changes over time in states' energy prices and environmental policies.

Taken all together, those lines of inquiry provide the most detailed decomposition of energy intensity across US states to date, and the paper begins to suggest explanations by examining correlations between declining energy intensity and other state characteristics. Two results stand out. First, the steep decline in US energy intensity is not explained by deindustrialization, either for the nation as a whole or on a state-by-state basis. Most of the decline can be explained by technique changes within the manufacturing sector. And second, 
state prices and policies are more closely associated with deindustrialization, which does not explain declining energy intensity, than with technique, which does.

Before detailing the analysis, it's important to acknowledge just a few of the many papers that have already touched on these issues and to note how this analysis differs from what has been done before.

\section{Prior Evidence: Decompositions, Convergence, and Regressions}

Versions of the questions posed here have been asked in many different ways. Most studies fall into one of four rough categories. They focus on comparisons across either countries or US states, and they use either decomposition or convergence analyses. Decomposition analyses explain the change in energy use as a function of underlying trends - population, income growth, industry composition, etc. Convergence analyses ask whether differences in energy use across countries are growing or shrinking (“converging”). Table 1 summarizes select studies, listing the data and methodologies used, main findings, and important figures or tables in those papers. Below I outline some highlights relevant to this paper.

\section{International Analyses}

Mulder and de Groot (2012) examine energy intensity - energy use per dollar of GDP -

for 18 countries in the Organisation for Economic Co-operation and Development (OECD) and 50 sectors. They show that the standard deviation of the log of energy intensity across countries fell from 1980 to 2005. That is, OECD countries' energy intensities are converging. Moreover, most of that convergence is explained by the decline in the standard deviation of energy intensities of the countries' manufacturing sectors. That finding and others like it are the reason that in this paper I focus attention on manufacturing.

Marrero and Ramos-Real (2013) study 15 EU countries using an approach similar to what I do here and arrive at a similar conclusion. Most of the decline in energy intensity comes within broad sectors (manufacturing, services) rather than across sectors. Like Mulder and de Groot, however, Marrero and Ramos-Real use only 50 sectors. Some within-sector composition changes may be misclassified as efficiency gains. An advantage I have in studying US states is that the manufacturing sector alone can be divided into almost 500 activities. 
Some of the studies contradict one another, although it's difficult to tell whether the conflicts arise from using different time periods, countries, sectors, or methodologies. Jakob et al. (2012) examine 15 countries and show that economic convergence - shrinking differences between rich and poor countries - has been accompanied by converging energy intensities. And Duro and Padilla (2011) expand the international analysis to 116 countries. Their results also support the conclusion that overall energy intensity differences across countries seem to be converging. By contrast, Kepplinger et al. (2013) focus on manufacturing and come to a slightly different conclusion. They note that countries with higher gross domestic product (GDP) industrialized countries - have industrial energy intensities that are both lower and falling faster than those of other countries. In other words, industrial energy intensity is diverging rather than converging.

In this paper I focus on the energy intensity of US states, an approach that enables me to study a far finer disaggregation among sectors than is possible internationally. I also worry less about convergence or divergence and simply describe the source of each state's manufacturing sector energy intensity changes, then explore how those sources might be related to state energy prices and policies.

\section{US State Analyses}

Metcalf's (2008) paper is closest in spirit to this paper. He first documents that overall energy intensity in the United States has declined steadily since 1970, and that only about onefourth of this decline can be explained by shifting among the residential, commercial, industrial, and transportation sectors. Most of the decline comes from reductions in energy intensity within sectors, which Metcalf calls efficiency. But if, say, the manufacturing sector shifts from producing energy-intensive goods like cement to less intensive products like electronics, calling that within-sector shift "efficiency" may be a mischaracterization. In this paper I study only the manufacturing sector and the shifts in the scale and composition of manufacturing as determined by 473 six-digit NAICS codes. Metcalf then conducts a state-by-state analysis to examine how much of the overall decline in energy intensity can be explained by state incomes or energy prices. I do the same but also consider various measures of regulatory policy. ${ }^{2}$

\footnotetext{
${ }^{2}$ See also van Benthem (2015) and Bernstein et al. (2003).
} 
Huntington (2010) presents an intermediate step between Metcalf's paper and this one. He disaggregates US economic activity into 65 subsectors, spread across the commercial, industrial, and transportation sectors. Huntington finds that almost 40 percent of the decline in energy intensity in the United States can be attributed to shifts among these sectors - 54 percent if we eliminate transportation. In this paper I disaggregate data from the nation to the individual states, and across 473 industries within the manufacturing sector alone.

Instead of studying energy efficiency itself, Bhole and Surana (2011) take the interesting strategy of examining state expenditures on energy efficiency. They find that state electricity prices are positively correlated with state expenditures, suggesting that high prices may induce state governments to invest in efficiency. There could be other explanations: perhaps states with constituents inclined toward energy efficiency enact regulations that raise energy prices. But the question is very much in the spirit and style of what I ask here: what state policies are associated with energy intensity declines in US states?

The simplest way to ask that question is to calculate

$$
\widehat{E}_{j t}=\sum_{i}\left(\frac{E_{i j, 1982}}{V_{i j, 1982}} V_{i j t}\right)
$$

This is the predicted total energy use $\left(\widehat{E}_{j t}\right)$ in jurisdiction $j$ and year $t$, where the prediction is calculated as the current value of output $\left(V_{i j t}\right)$ in sector $i$ times the sum, across sectors $i$, of the energy intensity in jurisdiction $j$ in the baseline year $1982\left(\frac{E_{i j, 1982}}{V_{i j, 1982}}\right)$. This prediction $\left(\widehat{E}_{j t}\right)$ is an estimate of what energy consumption would be in jurisdiction $j$ in year $t$ if each industry had its 1982 energy intensity - in other words, holding within-sector energy intensities fixed. The prediction allows the scale and composition of industries, but not the technique, to change over time.

Using equation (1), it is then possible to parse the changes in energy intensities in each state that are due to composition, the cross-industry changes in the relative shares of output coming from industries with different initial-year energy intensities, and those due to technique, the within-industry changes in energy intensity. Composition is just the difference between the 
prediction in (1) and what would have happened to total energy use if it had increased proportionally with output:

$$
\text { composition }=\Delta \% V_{j t}-\Delta \% \hat{E}_{j t}
$$

where $\Delta \% V_{j t}$ and $\Delta \% \hat{E}_{j t}$ are the percentage changes in output and energy, respectively, indexed so that 1982 equals 100. And technique is just the difference between this prediction and what actually happened to energy use:

$$
\text { technique }=\Delta \% \hat{E}_{j t}-\Delta \% E_{j t}
$$

again indexed so that 1982 equals 100.

For connoisseurs of index decomposition methods and terminology, note that the calculations in (1) to (3) amount to an extremely simple index - something like a Laspeyres index, where the base values used are the first year of the data series. A Laspeyres index is intuitive, with well-known properties, which is why I employ it here. It is used, for example, in the calculation of price inflation. It has its shortcomings, however. For prices, a Laspeyres index overstates inflation, and a Paasche index (the final-year counterpart) understates inflation. In this context, their relative sizes depend on whether the economy has shifted toward or away from energy-intensive industries. In Levinson (2015) I discuss and present both in the context of pollution intensity, with little significant difference. Ang and Zhang (2000) describe the extensive literature on index decompositions going back to Fisher (1921). ${ }^{3}$ But for this paper I stick with the basics, a simple forecast of 2007 energy consumption based on 1982 energy intensities. That prediction is in equation (1). The composition effect compares that prediction with proportional growth, in (2). And the technique effect compares that prediction with actual energy growth, in (3).

None of the calculations in equations (1) to (3) are complicated. The only difficulty involves obtaining data with a fine enough degree of disaggregation to separate the composition and technique effects. If the sectoral disaggregation of the economy is too course, some broad categories may have composition changes that get mislabeled as technique changes. For

\footnotetext{
${ }^{3}$ Also see Ang and Choi (1997) and Marrero (2010).
} 
example, the manufacturing sector has some industries that are energy intensive and others that are not. If we treat all of manufacturing as one sector in equation (1), we may then call some within-manufacturing reallocation of industries "technique" rather than "composition." In fact, I believe that this has been a feature of much of the prior research on this topic.

To study this composition-technique distinction carefully, I parse it into two parts. In the next section I examine the composition change between the industrial sector and the other uses of energy in the economy: transportation, commercial, and residential. And in the following section I focus on the manufacturing sector, disaggregated into 473 industries.

\section{The Declining Share of Industry in the US Economy}

At first glance, it appears that the declining share of the industrial sector in the overall US economy, in terms of both energy use and output, might explain the declining US energy intensity. Figure 3 plots the shares of overall energy use of the four sectors: industrial, residential, commercial, and transportation. Industry is the only sector that shrank.

Figure 4 contrasts changes in energy use by each sector with changes in overall output, measured differently for each sector. The first pair of shaded columns plots the total energy used by industry in 1982 and 2007, which rose from 28 quadrillion BTUs ("quads") to 32. But superimposed on the second of those columns is the (unshaded) projected 2007 industrial energy use, calculated by multiplying the 1982 energy use by the percentage change in industrial output, measured in inflation-adjusted dollars. Had industrial energy grown as fast as output, 2007 energy use would have been 52 quads rather than 32. The difference, represented by the unshaded gap, shows the declining energy intensity of US industry.

The second pair of columns in Figure 4 does the same thing for commercial buildings. In this case I don't have a good measure of the change in scale of output, so I use the square footage of commercial buildings. Energy use grew more, from 11 to 18, and energy intensity measured this way declined less. The third pair of columns does the same for residential buildings, where the scale effect is based on population growth. And finally, the last pair of columns scales the transportation sector's energy use by vehicle miles traveled. This last case does appear to rival industry in terms of its contribution to declining US energy intensity. But transportation is nontradable. We cannot import our commutes to work, thereby shifting the resulting pollution 
from the United States to other countries. And so for transportation energy use, there's less concern about the composition-technique distinctions.

Figure 5 plots the scale, composition, and technique changes to US energy use, where the sectors are defined broadly as either "industrial" or "other." So the composition effect here is really "deindustrialization." The bottom line, "Energy," plots the total energy used in the United States, indexed so that 1982 equals 100. Energy use grew by 39 percent. The top line, "Scale," is just the real value of GDP, which grew by 125 percent. The middle line, "Scale and Deindustrialization," is the estimate of $\widehat{E}_{j t}$ from equation (1), indexed so that 1982 equals 100 , using only the two broad sectors "industrial" and "other." The top two lines are quite close, suggesting that most of the decline in energy intensity has come from within the industrial sector, not between the industrial and other sectors - that is, it is not due to deindustrialization.

Figure 6 presents that same information in a slightly different way, dividing by scale so that contributions to energy intensity can be seen more directly. The bottom line depicts the overall energy intensity of the United States, which fell by 38 percent to 62 (indexed so that 1982 equals 100). And the top line depicts the decline in overall energy intensity explained by the declining share of industry in overall output. That line falls much less, by only 8 percent. Again, most of the decline in energy intensity must be within the industrial sector.

Finally, that same pattern holds across US states. Figure 7 plots that middle line - the decline in energy intensity due to the changing industrial share of GDP - for each US state. For most states the industrial share is less than 10 percent. For some, where industrial output grew as a share of gross state product, it is even positive.

These analyses all suggest that the biggest contributor to declining energy intensity in the United States has come within the manufacturing sector. That sector also raises the largest concerns about whether declining energy intensity has been the result of changes in the mix of goods manufactured (composition) or reductions in the amount of energy required to produce each good (technique). 


\section{Manufacturing Changes: Composition or Technique?}

US states exhibit heterogeneity in the 25-year change in energy intensity within the industrial sector, just as much as they do overall. Figure 8 presents a version of Figure 2 using only industrial energy use - output per dollar of value added without transportation, commercial, or residential energy. Although the individual state lines exhibit more year-to-year noise, the basic trends are nearly identical. Industrial energy intensity fell by 67 percent on average for the nation but rose by 20 percent in Alaska and fell by 90 percent in Oregon.

Figure 9 plots indexes of energy use in the United States. The bottom line, "Energy," is simply the total energy used by the US manufacturing sector, indexed so that 1982 equals $100 .^{4}$ The top line, "Scale and Composition," is the estimate of $\widehat{E}_{j t}$ from equation (1). This is calculated using the 473 six-digit NAICS codes in the manufacturing sector. And the middle line, "Scale," is just the real value of total manufacturing sales, indexed to 1982.

As Figure 9 shows, manufacturing output grew 121 percent over 25 years, but manufacturing energy use grew only 22 percent. This difference represents a huge decline in energy intensity. Does it come from composition changes across industries, or from changes in technique within six-digit industries? In fact, for the United States, the composition effect works against the trend. If every industry continued using its 1982 energy intensity, the changing scale and composition of US manufacturing would have led to a 330 percent increase in total energy use. So in aggregate, for the US manufacturing sector, the composition effect increased energy consumption by 209 percentage points, and the technique effect reduced energy consumption by 308 percentage points.

To be clear, nothing about Figure 9 suggests a causal relationship. Several researchers have documented a "pollution-haven" effect: jurisdictions with strict environmental regulations, or where environmental regulations have become stricter, have seen a modest but statistically significant shift in their industrial compositions toward less pollution-intensive and energyintensive industries, all else equal ${ }^{5}$ - the critical phrase being those last three words. That US manufacturing is energy intensive and has shifted toward more energy-intensive industries over

\footnotetext{
${ }^{4}$ Source: NBER-CES Manufacturing Industry Database (www.nber.org/nberces).

${ }^{5}$ See Kahn and Mansur (2013), Mulatu et al. (2010), or Levinson and Taylor (2008).
} 
time should not be surprising, since energy costs are low in the United States, relative to other countries, ${ }^{6}$ and labor costs are high. What would be surprising, however, is if rising prices or stricter environmental policies did not cause a shift toward less energy-intensive composition, relative to what that composition would have been absent those prices and policies.

Do prices or polices affect the shift in composition? We cannot answer that question with just one observation, the entire nation. And so the next step is to calculate equations (1) to (3) on a state-by-state basis and examine whether the differences across states are associated with differences in state energy prices or policies.

\section{State-Specific Estimates}

To calculate state-specific changes in the manufacturing sector's energy composition, I combine annual state energy data from the US Energy Information Administration (EIA) with the 1982 and 2007 Censuses of Manufactures. ${ }^{7}$ I then calculate versions of equation (1) for those two years for each state. ${ }^{8}$

To demonstrate the analysis, examine two large states with opposite scenarios: California and Texas. Figure 10 plots a version of Figure 9 for California alone. If the California manufacturing sector's energy use had grown proportionately with its output, energy use would have grown 86 percent ("Scale"). The predicted energy growth $\widehat{E}_{j t}$, based on changes in the scale and composition of the manufacturing sector, grew by 64 percent. The difference between those two represents the composition changes that, in this case, reduced the state's manufacturing energy use. So California shifted toward less energy-intensive industries, unlike the nation as a whole. The state's industrial energy use grew 36 percent, and the difference between that relatively low growth rate and the predicted 64 percent growth rate represents within-industry technique. The explanation for California's declining energy intensity, then, can be divided fairly evenly between composition and technique, with technique accounting for a little more than half of the gains.

\footnotetext{
${ }^{6}$ www.gov.uk/government/statistical-data-sets/international-industrial-energy-prices.

7 The EIA data are called the State Energy Data System (SEDS); www.eia.gov/state/seds/sedsdata-complete.cfm.

${ }^{8}$ State-specific manufacturing output data are not available by six-digit NAICS code for the years in between the five-year censuses.
} 
Contrast that with Texas, depicted in Figure 11. Texas's pattern looks more like the national case. A proportional increase in Texas's manufacturing output would have increased manufacturing energy use by 122 percent. Composition and scale together $\left(\widehat{E}_{j t}\right)$ would have increased energy use by 180 percent. Whereas California's manufacturing sector shifted toward less energy-intensive goods, Texas's shifted in the opposite direction, toward industries that use more energy.

In Appendix Table A1, I describe this result for all 48 contiguous US states in columns 3, 4, and 5. The result displays remarkable heterogeneity. Energy use by manufacturing (column 3) fell 47 percentage points in Maryland and grew 197 percent in North Dakota. Composition changes shaved 1,055 percentage points off energy growth in Nevada but added 297 percentage points in Delaware. And technique accounts for an additional 750 percentage points of energy reductions in Nevada but only 127 percentage points of extra energy use in New Mexico.

What explains the difference between California and Texas, and all the other differences across states? Why did California's industrial composition shift toward less energy-intensive industries while Texas's shifted toward more energy-intensive industries? And why was Texas's technique effect - the within-industry energy-intensity decline - larger than California's? Could the explanation be energy prices or some other regulatory policy differences between the states? The next section attempts to answer those questions by comparing differences across all states.

\section{State Prices and Polices}

In this section I pose a simple question: what state prices and policies are correlated with states' changing industrial compositions or technique effects? Note that I am careful not to ascribe causation to these correlations; I will repeat that caution several times below. However, it seems like an interesting and important first step to ask whether those states that have enacted energy efficiency standards or seen rising energy prices or been most affected by the US Clean Air Act are also the states whose industrial composition has shifted more toward less energyintensive industries or whose industries have seen the largest technique improvements in energy efficiency. If those improvements are correlated with prices and policies, a natural next step (for another paper) would be to determine whether those relationships are causal. If the improvements are not correlated, the next step would be to determine whether the effect is 
masked here by another unobserved or simultaneous relationship, or whether the prices and policies enacted really have no measurable effect on energy intensity.

Appendix Table A1 reports the data for two measures of changes in states' energy intensities. The first two columns examine the share of the economy-wide decline in energy intensity that is due to a drop in the industrial sector's importance to the overall economy. The discussion above suggests that in general, declining industry does not explain the US energy intensity decline. But for some individual states the share is larger, and it remains of interest how much that decline may be correlated with state prices and policies.

Columns 3, 4, and 5 of Appendix Table A1 turn to the manufacturing sector and examine separately each of the components of declining energy intensity. Column 3 is an index of total manufacturing energy use (1982 equals 100), which ranges from 53 in Maryland (a 47 percent decline) to 297 in North Dakota (a 197 percent increase). Column 4 contains an estimate of the composition change and its contribution to the state's decline in manufacturing energy intensity, from equation (2). The state where composition shifted the most toward energy-using industries is Delaware. If every industry in Delaware retained its 1982 energy intensity, that state's 2007 manufacturing energy use would have been 197 percentage points larger. The state where composition shifted the most toward industries using less energy is Nevada. Column 5 presents the technique effect from equation (3), which ranges from -27 percent in New Mexico to +650 percent in Nevada.

To what extent are variations in these measures of state energy intensity associated with states' prices or policies? Appendix Table A2 gives some measures of those state characteristics, and Table 2 reports their correlations with the measures of energy intensity, starting with prices.

Columns 1 and 2 of Table A2 report the percentage change in the price of electricity and the average absolute price of electricity, respectively, from 1982 to $2007 .{ }^{9}$ Table 2 reports the correlations between these measures of state energy prices and the five measures of state energy intensity reported in Appendix Table A1. States with high prices (row 1) or steeply rising prices

\footnotetext{
${ }^{9}$ I use state electricity prices for the industrial sector, from the US Energy Information Administration, because that series is available for all years and states in this sample. Michielsen (2013) shows that "Coal abundance primarily affects industry location through lower electricity prices."
} 
(row 2) had higher-than-average declines in overall energy intensity (column 1). And for states with high prices, a larger-than-average share of that decline came from industry's declining share of gross state product (GSP). That declining industry share is also reflected in column 3, the scale effect of manufacturing. We cannot make too much of these correlations, of course. They are, after all, not demonstrations of causation. States with growing manufacturing sectors may put upward pressure on energy prices. But it does seem that states with the highest and fastestgrowing energy prices saw the steepest declines in the industrial sector as a share of GSP and in the scale of the manufacturing portion of the industrial sector. That said, the earlier discussion demonstrates that the shrinking role of manufacturing accounts for only a small part of states' declining energy intensities.

Column 3 of Appendix Table A2 contains the year the state first implemented energy efficiency standards for building codes, from Aroonruengsawat et al. (2012). This is intended as an indicator for broader concerns about energy efficiency. Table 2 reports the correlations between the year of building code establishment and the five measures of energy intensity. There seems to be no correlation.

Columns 4 and 5 of Appendix Table A2 explore environmental policies. There are numerous approaches to measuring the stringency of these policies. Galeotti et al. (2015) discuss various measures of environmental and energy policy stringency and develop their own crosscountry measure based on Brunel and Levinson (2015). Here we use that same approach but for US states, from an index developed in Keller and Levinson (2002). ${ }^{10}$ Column 4 of Table A2 contains the average PACE index from 1973 to 1994, and column 5 contains the change. As

\footnotetext{
${ }^{10}$ The index is based on the US Pollution Abatement Costs and Expenditures (PACE) survey, conducted annually by the US Census Bureau from 1973 until 1994. The Census Bureau published the average annual abatement expenditures by industry and by state. Keller and Levinson (2002) use those published data to calculate the total costs per dollar of manufacturing value added: $S_{s t}=P_{s t} / Y_{s t}$, where $P_{s t}$ is the pollution abatement cost in state $s$ in year $t$, and $Y_{s t}$ is the manufacturing sector's value added state $s$ in year $t$. They compare that to the predicted abatement costs, $\hat{S}_{s t}$, a weighted average of the national pollution abatement costs for each of 20 industries, where the weights are the industries' shares of output in state $s, Y_{\text {sit }} / Y_{i t}$. Keller and Levinson's measure of stringency is just the ratio of actual over predicted costs, $S_{s t} / \hat{S}_{s t}$. When this ratio is greater than one, pollution abatement costs are larger than would be expected given the state's industrial composition, and Keller and Levinson infer that the state's regulations are relatively stringent.
} 
reported in Table 2, neither is particularly strongly correlated with the states' change in total manufacturing energy use, composition, or technique. However, states with high average PACE indexes do seem to have a larger share of their energy intensity declines explained by shrinking industrial sectors.

Columns 6 and 7 of Appendix Table A2 list the shares of state government spending on "parks, libraries, arts and humanities" and "infrastructure and communication," respectively, both from Islam (2013). Back in Table 2, spending on parks appears negatively correlated with the industrial decline's share of energy intensity decline, positively correlated with manufacturing energy growth, and positively correlated with composition change toward less energy-intensive industries. I suspect that what's really happening is that states with the fastest economic growth spend more on parks - a normal public good that increases with income - and that those states have a large increase in manufacturing energy use but an even larger increase in manufacturing output, offset by energy reductions due to composition and technique.

Column 8 of Appendix Table A2 presents another measure of environmental policy: the share of the state's population living in counties declared out of attainment with federal ambient air quality standards. Nonattainment has been used as a measure of stringency by Henderson (1996), Becker and Henderson (2000), and others. Counties that have poor air quality and do not meet federal standards are required by the US Clean Air Act to impose tough regulations to try to come into compliance, and that distinction has been interpreted as an exogenously imposed environmental standard. As reported in Table 2, states with higher shares of their populations living in nonattainment counties saw larger drops in industry's share of GSP, a larger drop in overall energy use, and a bigger within-industry (technique) decline in energy intensity.

Columns 9 and 10 of Appendix Table A2 give indexes of regulatory policy. The American Council for an Energy Efficient Economy (ACEEE) publishes an annual "scorecard" designed to assess "the progress of state policies and programs that save energy while also benefiting the environment and promoting economic growth." ${ }^{11}$ Column 9 contains the ACEEE scorecard for 2006, the first year it was published. In Table 2 this index is correlated with the decline in industry's share of GSP and the slower growth of the manufacturing sector but not

\footnotetext{
${ }^{11}$ www.aceee.org.
} 
with the composition or technique effects. The League of Conservation Voters (LCV) publishes a different index - also called a scorecard - based on the pro-environmental voting record of states' congressional delegations. Like the ACEEE scorecard, the LCV scorecard is negatively correlated with overall manufacturing energy growth but not with the composition or technique effects.

Finally, and perhaps most importantly, the last column of Appendix Table 2 contains the growth in real gross state product per capita from 1982 to 2007 . At the bottom of Table 2, GSP growth is correlated with declining energy intensity, negatively correlated with the proportion of that decline coming from deindustrialization, and uncorrelated with the scale, composition, or technique of the manufacturing sector.

\section{Conclusions}

Although the United States as a whole has experienced a large decline in energy intensity over the past 25 years, individual states exhibit considerable heterogeneity in energy per dollar of output, with some state intensities decreasing much more than the national average and some increasing. This paper shows that deindustrialization has not played a significant role in declining energy intensity, either for the nation as a whole or on a state-by-state basis. Much of the declining energy intensity has been due to changes within the manufacturing sector.

I have correlated those cross-sector and within-sector changes with measures of state energy prices and policies. Although prices and policies do seem to be associated with deindustrialization, they are not correlated with the within-manufacturing technique changes that explain the bulk of energy intensity declines in the United States. In other words, the prices and policies appear correlated with changes to states' economies that are the least important determinants of energy intensity. 


\section{References}

Ang, B.W. and Choi, K.H. 1997. "Decomposition of aggregate energy and gas emission intensities for industry: A refined Divisia index method." Energy Journal 18: 59-73.

Ang, B.W. and F.Q. Zhang. 2000. "A survey of index decomposition analysis in energy and environmental studies.” Energy 25: 1149-76.

Aroonruengsawat, A., M. Auffhammer and A.H. Sanstad. 2012. "The impacts of state level building codes on residential electricity consumption." Energy Journal 33(1): 31-52

Baldwin, J.G. and I. Sue Wing. 2013. "The spatiotemporal evolution of U.S. carbon dioxide emissions: Stylized facts and implications for climate policy spatiotemporal evolution of U.S. carbon dioxide emissions." Journal of Regional Science 53(4): 672-89.

Becker, R.A. and J.V. Henderson. 2000. "Effects of air quality regulations on polluting industries." Journal of Political Economy 108: 379-421.

Bernstein, M., K. Fonkych, S. Loeb, and D. Loughran. 2003. "State-level changes in energy intensity and their national implications." RAND Monograph Report MR-1616-DOE.

Bhole, B. and S. Surana. 2011. "Electricity prices and state commitment to energy efficiency in the U.S." Energy Efficiency 4(1): 9-16.

Brunel, C. and A. Levinson. 2016. "Measuring environmental regulatory stringency." Review of Environmental Economics and Policy, 10(1): 47-67.

Coccia, M. 2010. "Energy metrics for driving competitiveness of countries: Energy weakness magnitude, GDP per barrel and barrels per capita." Energy Policy 38(3): 1330-1339.

Duro, J.A. and E. Padilla. 2011. "Inequality across countries in energy intensities: An analysis of the role of energy transformation and final energy consumption." Energy Economics 33: 474-79.

Drummond, W.J. 2010. "Statehouse versus greenhouse: Have state-level climate action planners and policy entrepreneurs reduced greenhouse gas emissions?" Journal of the American Planning Association 76(4): 413-33.

Fisher, I. 1921. "The best form of index number." Quarterly Publications of the American Statistical Association 17(133): 533-37.

Galeotti, M., S. Salini and E. Verdolini. 2015. "Measuring environmental policy stringency: Approaches, validity, and impact on energy efficiency." Working paper.

Henderson, V. 1996. "Effects of air quality regulation.” American Economic Review 86: 789813. 
Huntington, H.G. 2010. "Structural change and US energy use: Recent patterns.” Energy Journal 31(3): 25-39.

Islam, A.M. 2013. "US government spending allocation database by state (SADS)." Working paper 147368. University of Maryland, Department of Agricultural and Resource Economics.

Jakob, M., M. Haller and R.T. Marschinski. 2012. "Will history repeat itself? Economic convergence and convergence in energy use patterns." Energy Economics 34: 95-104.

Kahn, M. and E. Mansur. 2013. "Do local energy prices and regulations affect the geographic concentration of employment?" Journal of Public Economics 101: 105-114.

Keller, W. and A. Levinson. 2002. "Pollution abatement costs and foreign direct investment inflows to U.S. states." Review of Economics and Statistics 84(4): 691-703.

Kepplinger, D. M. Templ and S. Upadhyaya. 2013. "Analysis of energy intensity in manufacturing industry using mixed-effects models.” Energy 59: 754-63.

Levinson, A. 2015. "A direct estimate of the technique effect: Changes in the pollution intensity of US manufacturing, 1990-2008." Journal of the Association of Environmental and Resource Economists 2(1): 43-56.

Levinson, A. and M.S. Taylor. 2008. "Unmasking the pollution haven effect." International Economic Review 49: 223-54.

Liddle, B. 2009. "Electricity intensity convergence in IEA/OECD countries: Aggregate and sectoral analysis.” Energy Policy 37: 1470-78.

Marrero, G.A. 2010. "Greenhouse gases emissions, growth and the energy mix in Europe.” Energy Economics 32(6): 1356-63.

Marrero, G. and F. Ramos-Real. 2013. “Activity sectors and energy intensity: Decomposition analysis and policy implications for European countries (1991-2005)." Energies (Basel) 6(5): 2521-40.

Metcalf, G.E. 2008. "An empirical analysis of energy intensity and its determinants at the state level." Energy Journal 29(3): 1-26.

Michielsen, T.O. 2013. "The distribution of energy intensive sectors in the USA." Journal of Economic Geography 13(5): 871-88.

Mulatu, A., R. Gerlagh, D. Rigby and A. Wossing. 2010. "Environmental regulations and industry location in Europe." Environmental and Resource Economics 45: 459-79. 
Mulder, P. and H.L.F. de Groot. 2012. "Structural change and convergence of energy intensity across OECD countries, 1970-2005.” Energy Economics 34(6): 1910-21.

Sue Wing, I. 2008. "Explaining the declining energy intensity of the US economy." Resource and Energy Economics 30: 21-49.

Tol, R.S.J. 2009. "Understanding long-term energy use and carbon dioxide emissions in the USA." Journal of Policy Modeling 31(3): 425-45.

van Benthem, A.A. 2015. "Energy leapfrogging." Journal of the Association of Environmental and Resource Economists 2(1): 93-132.

Weber, C.L. 2009. "Measuring structural change and energy use: Decomposition of the US economy from 1997 to 2002." Energy Policy 37(4): 1561-70. 


\begin{tabular}{|c|c|c|c|c|}
\hline Paper & Data & Methodology & Main Finding & Key Cite \\
\hline \multicolumn{5}{|l|}{ US States } \\
\hline $\begin{array}{l}\text { Metcalf } \\
(2008)\end{array}$ & US states, 1970-2001 & $\begin{array}{l}\text { Decomposition at } \\
\text { state and national } \\
\text { levels }\end{array}$ & $\begin{array}{l}\text { Declines in energy intensity are explained by } \\
\text { "energy efficiency," broadly defined. }\end{array}$ & Table 3. pl.10 \\
\hline $\begin{array}{l}\text { Weber } \\
(2009)\end{array}$ & $\begin{array}{l}\text { US industries, 1997- } \\
2002\end{array}$ & $\begin{array}{l}\text { I-O analysis, structural } \\
\text { decomposition } \\
\text { analysis }\end{array}$ & $\begin{array}{l}\text { Changes in the structure of the economy } \\
\text { explain drop in total energy intensity more than } \\
\text { increased energy efficiency. }\end{array}$ & $\begin{array}{l}\text { Figure 4; } \\
\text { Tables 2, } 3\end{array}$ \\
\hline Tol (2009) & US, 1850-2002 & $\begin{array}{l}\text { Decomposition at } \\
\text { national level }\end{array}$ & $\begin{array}{l}\text { Energy intensity declined because of } \\
\text { technological and behavioral changes, } \\
\text { structural change in economy, shift from coal to } \\
\text { oil and gas. }\end{array}$ & Figure 8 \\
\hline $\begin{array}{l}\text { Drummond } \\
(2010)\end{array}$ & US, 1990-2007 & Regression analysis & $\begin{array}{l}\text { State-level climate actions have modest effect } \\
\text { on GHG emissions. }\end{array}$ & - \\
\hline $\begin{array}{l}\text { Huntington } \\
(2010)\end{array}$ & $\begin{array}{l}5 \text { sectors, 1949-1996; } \\
65 \text { NAICS industries, } \\
1997-2006\end{array}$ & Decomposition & $\begin{array}{l}\text { Structural changes in economy account for } \\
\text { much of reduction in energy intensity. }\end{array}$ & Tables 1, 4 \\
\hline Bhole (2011) & $\begin{array}{l}\text { State-level, } \\
\text { noncontiguous years } \\
\text { from } 1993 \text { to } 2004\end{array}$ & Regression & $\begin{array}{l}\text { Electricity prices have significant positive effect } \\
\text { on state energy efficiency expenditures. }\end{array}$ & Table 4 \\
\hline $\begin{array}{l}\text { Baldwin and } \\
\text { Sue Wing } \\
\text { (2013) }\end{array}$ & US states, 1963-2008 & $\begin{array}{l}\text { Index number } \\
\text { decomposition }\end{array}$ & $\begin{array}{l}\text { Carbon emissions among states are } \\
\text { stochastically converging; } 2010 \mathrm{EIA} \\
\text { underestimates future carbon emissions. }\end{array}$ & Figure 3 \\
\hline $\begin{array}{l}\text { Sue Wing } \\
(2008)\end{array}$ & $\begin{array}{l}35 \text { economic sectors } \\
\text { (2-digit level), 1958- } \\
2000\end{array}$ & $\begin{array}{l}\text { Decomposition, } \\
\text { comparison among } \\
\text { industries }\end{array}$ & $\begin{array}{l}\text { Interindustry structural change caused } \\
\text { decrease in US energy intensity until 1973; } \\
\text { intraindustry efficiency improvements had } \\
\text { significant effect on energy intensity post-1980. }\end{array}$ & Table 5 \\
\hline
\end{tabular}




\section{International}

\begin{tabular}{|c|c|c|c|c|}
\hline $\begin{array}{l}\text { Coccia } \\
(2010)\end{array}$ & $\begin{array}{l}\text { Eurostat (32 European } \\
\text { countries), 1996-2007 }\end{array}$ & $\begin{array}{l}\text { Energy metrics, } \\
\text { decomposition }\end{array}$ & $\begin{array}{l}\text { GDP per barrel of oil best indicates energy } \\
\text { productivity. Barrels of oil per capita best } \\
\text { indicate energy efficiency. }\end{array}$ & Figure 3 \\
\hline $\begin{array}{l}\text { Mulder and } \\
\text { de Groot } \\
(2012)\end{array}$ & $\begin{array}{l}18 \text { OECD countries, } 50 \\
\text { sectors, } 1970-2005\end{array}$ & $\begin{array}{l}\text { Decomposition, } \\
\text { convergence analysis }\end{array}$ & $\begin{array}{l}\text { Convergence patterns of energy intensity occur } \\
\text { more within sectors than between sectors; } \\
\text { manufacturing had greatest decrease in energy } \\
\text { intensity over time. }\end{array}$ & Figure 1 \\
\hline $\begin{array}{l}\text { Marrero and } \\
\text { Ramos-Real } \\
(2013)\end{array}$ & $\begin{array}{l}15 \text { EU countries, } 1991- \\
2005\end{array}$ & Decomposition & $\begin{array}{l}\text { Efficiency, not structure, explains variation } \\
\text { between countries. }\end{array}$ & Figure 5 \\
\hline $\begin{array}{l}\text { Kepplinger et } \\
\text { al. (2013) }\end{array}$ & $\begin{array}{l}\text { UNIDO, } 163 \text { countries, } \\
\text { 2-digit industrial codes } \\
\text { for manufacturing } \\
\text { industry, 1963-2009; } \\
\text { MVA, 200+ economies, } \\
1990-2012\end{array}$ & - & $\begin{array}{l}\text { Countries with higher GDP have lower energy } \\
\text { intensity; energy efficiency is achieved along } \\
\text { with technological advancement. }\end{array}$ & Figures 3, 4 \\
\hline $\begin{array}{l}\text { Duro and } \\
\text { Padilla } \\
\text { (2011) }\end{array}$ & $\begin{array}{l}\text { IEA, } 116 \text { countries, } \\
\text { 1971-2006. }\end{array}$ & Theil decomposition & $\begin{array}{l}\text { Energy intensity has diverged in four of nine } \\
\text { regions, converged in others. }\end{array}$ & Tables 4, 5 \\
\hline $\begin{array}{l}\text { Jakob et al. } \\
(2012)\end{array}$ & $\begin{array}{l}30 \text { developing } \\
\text { countries, } 21 \\
\text { industrialized countries, } \\
1971-2005\end{array}$ & Convergence analysis & $\begin{array}{l}\text { Developing countries have above-average } \\
\text { energy intensities; industrialized countries have } \\
\text { larger improvements in energy efficiency. }\end{array}$ & Table 4 \\
\hline Liddle (2009) & $\begin{array}{l}22 \text { developed } \\
\text { countries, 1960-2006 }\end{array}$ & Convergence analysis & $\begin{array}{l}\text { Electricity intensity has converged less than } \\
\text { aggregate energy intensity. }\end{array}$ & - \\
\hline
\end{tabular}


Table 2. Correlations: Energy Intensity, Composition, Prices, and Regulations in US States, 1982-2007

\section{Economy-wide energy intensity}

Industrial energy changes

\begin{tabular}{|c|c|c|c|c|c|}
\hline & $\begin{array}{c}\text { Percentage point } \\
\text { decline in energy } \\
\text { intensity } \\
\end{array}$ & $\begin{array}{l}\text { Proportion due to } \\
\text { declining share of } \\
\text { industry in GDP }\end{array}$ & Scale & Composition & Technique \\
\hline & (1) & (2) & (3) & (4) & (5) \\
\hline \multicolumn{6}{|l|}{ Prices, 1982-2007 } \\
\hline Average & $0.35^{*}$ & $-0.34 *$ & $-0.37 *$ & 0.05 & -0.02 \\
\hline Change & $0.34^{*}$ & 0.21 & $-0.26 *$ & 0.13 & 0.10 \\
\hline Year of first building code & 0.13 & 0.06 & -0.11 & 0.11 & 0.12 \\
\hline \multirow{2}{*}{\multicolumn{6}{|c|}{$\begin{array}{l}\text { Pollution Abatement Costs and } \\
\text { Expenditures (PACE) index }\end{array}$}} \\
\hline & & & & & \\
\hline Average & 0.12 & $0.50^{*}$ & -0.09 & -0.21 & -0.05 \\
\hline Change & -0.17 & 0.14 & -0.01 & 0.07 & -0.17 \\
\hline \multicolumn{6}{|l|}{ Public spending shares } \\
\hline Parks & 0.04 & $-0.27^{*}$ & $0.39 *$ & $0.38^{*}$ & $0.30^{*}$ \\
\hline Infrastructure & -0.14 & -0.03 & $0.32^{*}$ & 0.04 & 0.23 \\
\hline $\begin{array}{l}\text { Share of population in nonattainment } \\
\text { counties }\end{array}$ & $0.36^{*}$ & -0.18 & $-0.30 *$ & 0.12 & $0.33^{*}$ \\
\hline \multicolumn{6}{|l|}{ NGO indexes } \\
\hline ACEEE & $0.58^{*}$ & -0.19 & $-0.37 *$ & 0.09 & -0.03 \\
\hline League of Conservation Voters & -0.09 & 0.15 & $-0.28 *$ & -0.13 & -0.16 \\
\hline Economic growth per capita & $0.38^{*}$ & $-0.45^{*}$ & -0.06 & -0.20 & -0.21 \\
\hline
\end{tabular}

*Statistically significantly different from zero at $5 \%$. 
Figure 1. Countries' Energy Use per Dollar of GDP

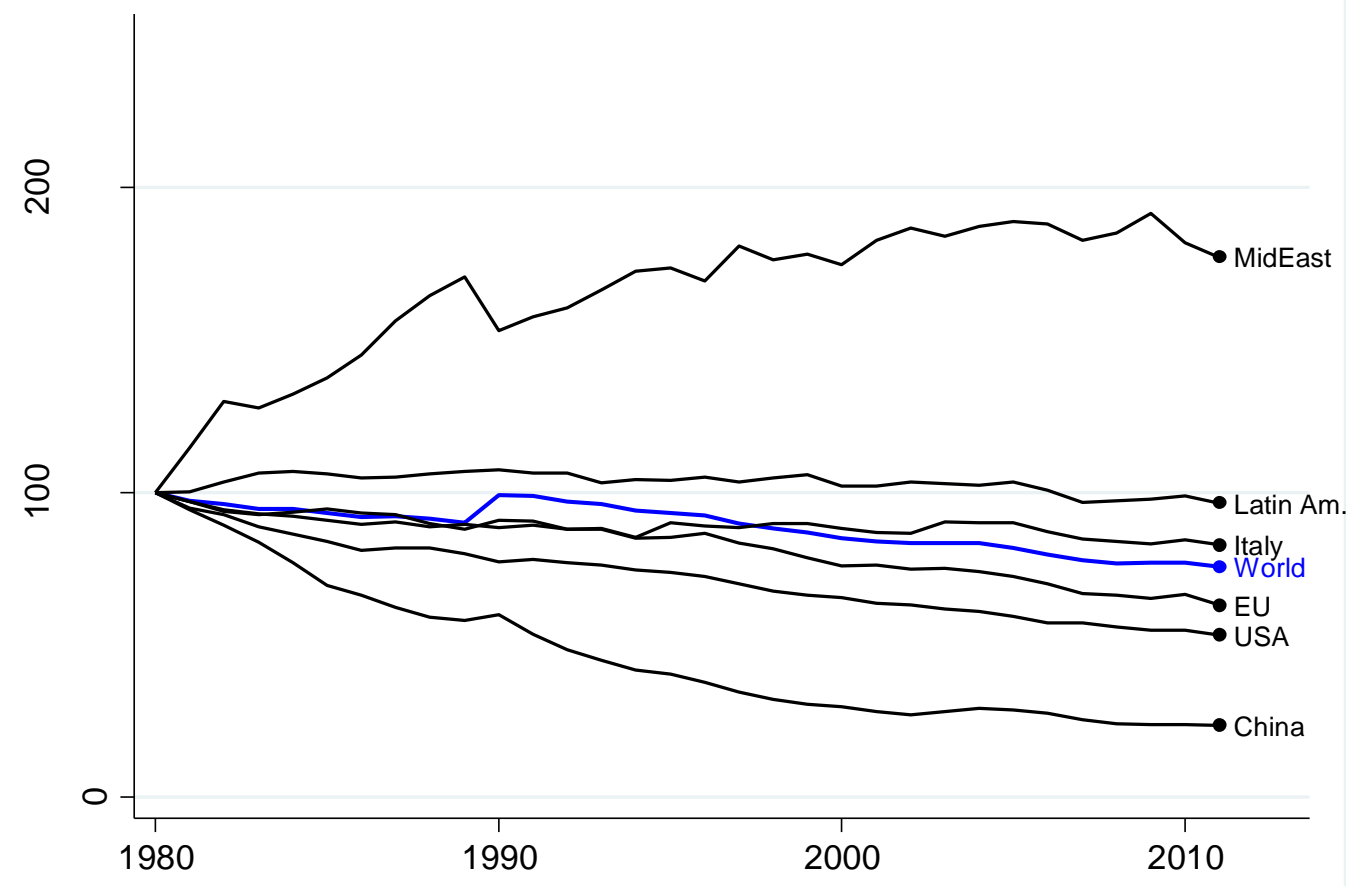

Source: World Bank World Devlopment Indicators, kg oil equivalent, constant 2005 PPP \$

Figure 2. US States' Energy Use per Dollar of Gross State Product

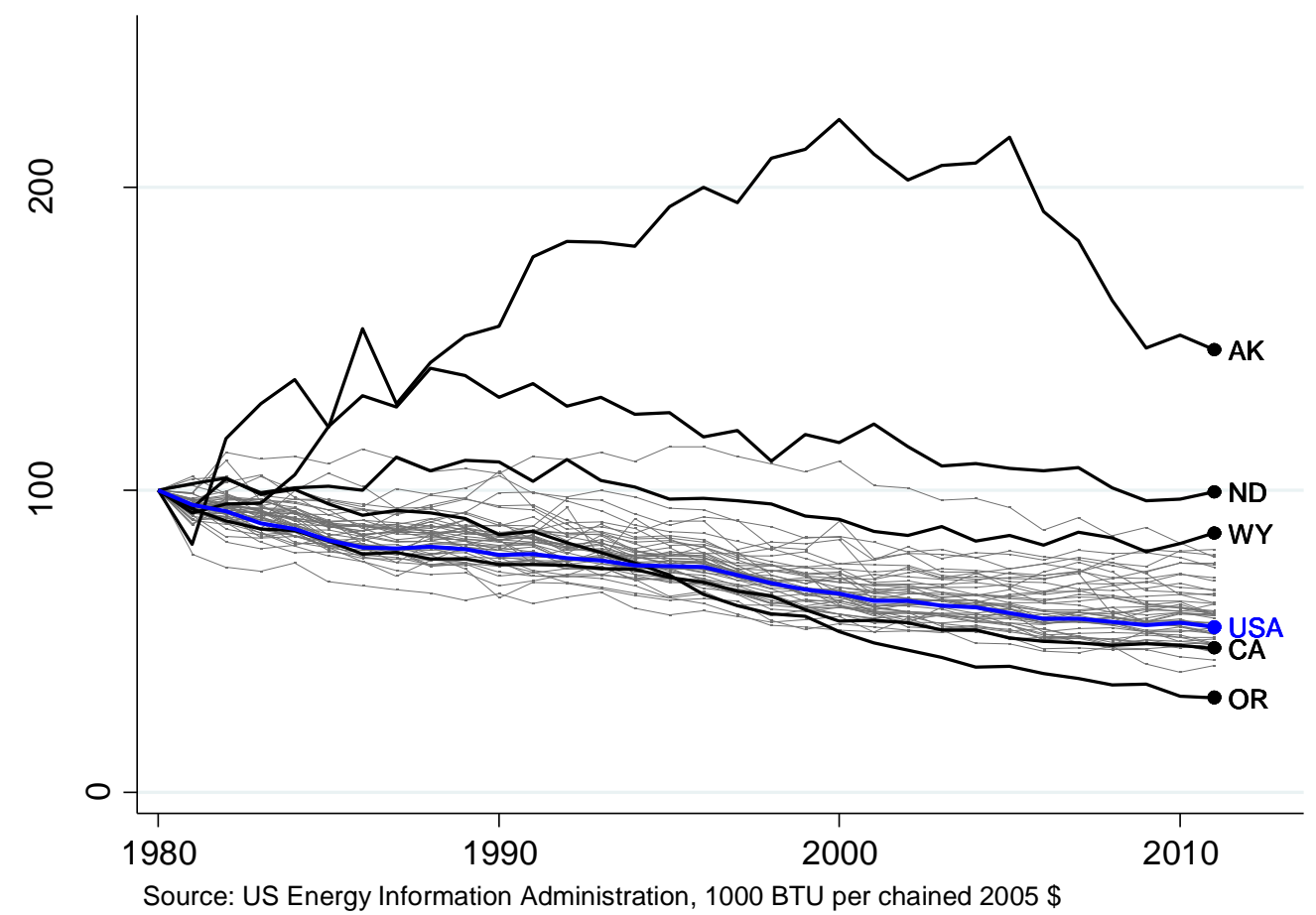


Figure 3. Sector Shares of US Energy Use

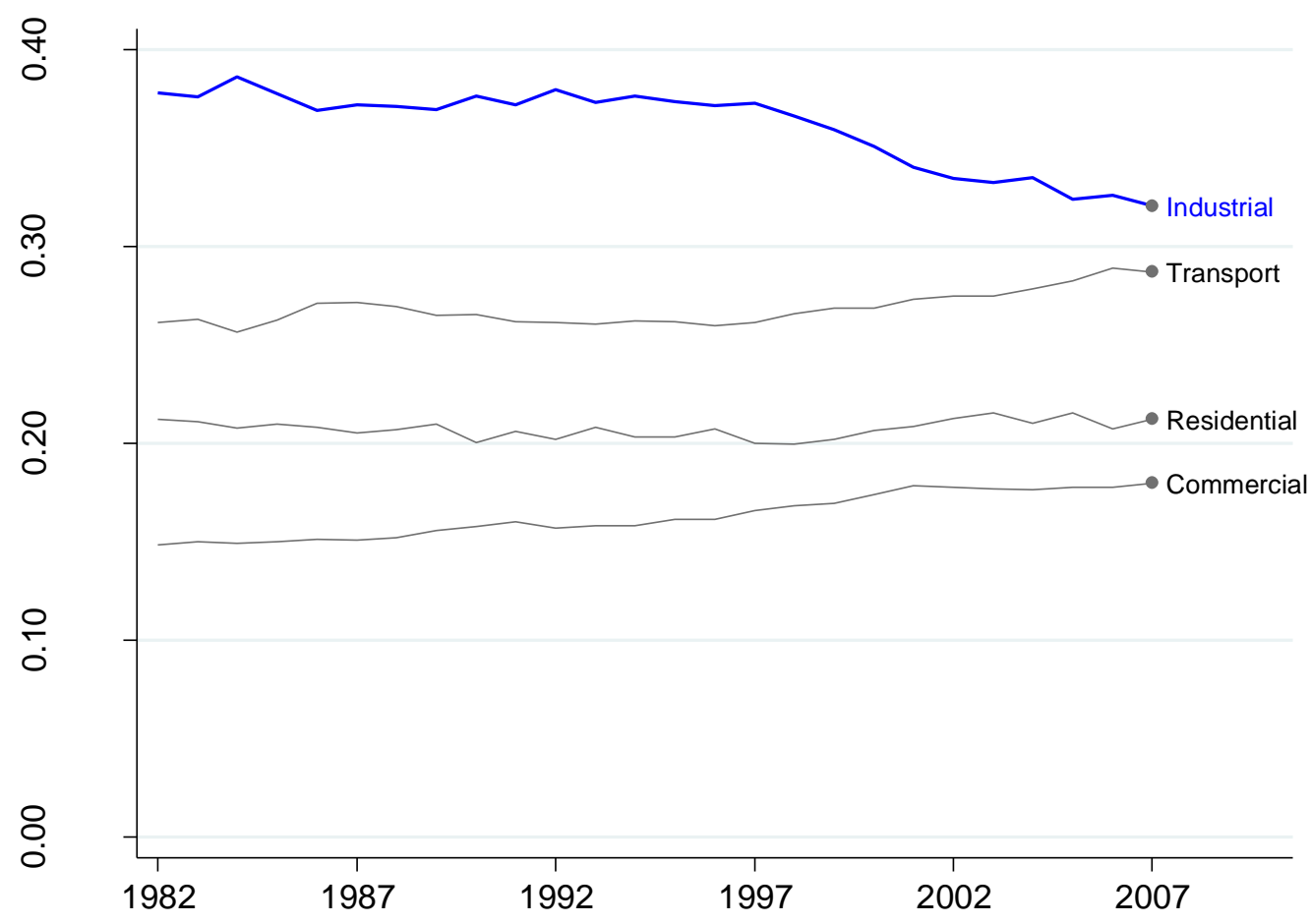

Figure 4. Total US Energy, Actual and Projected

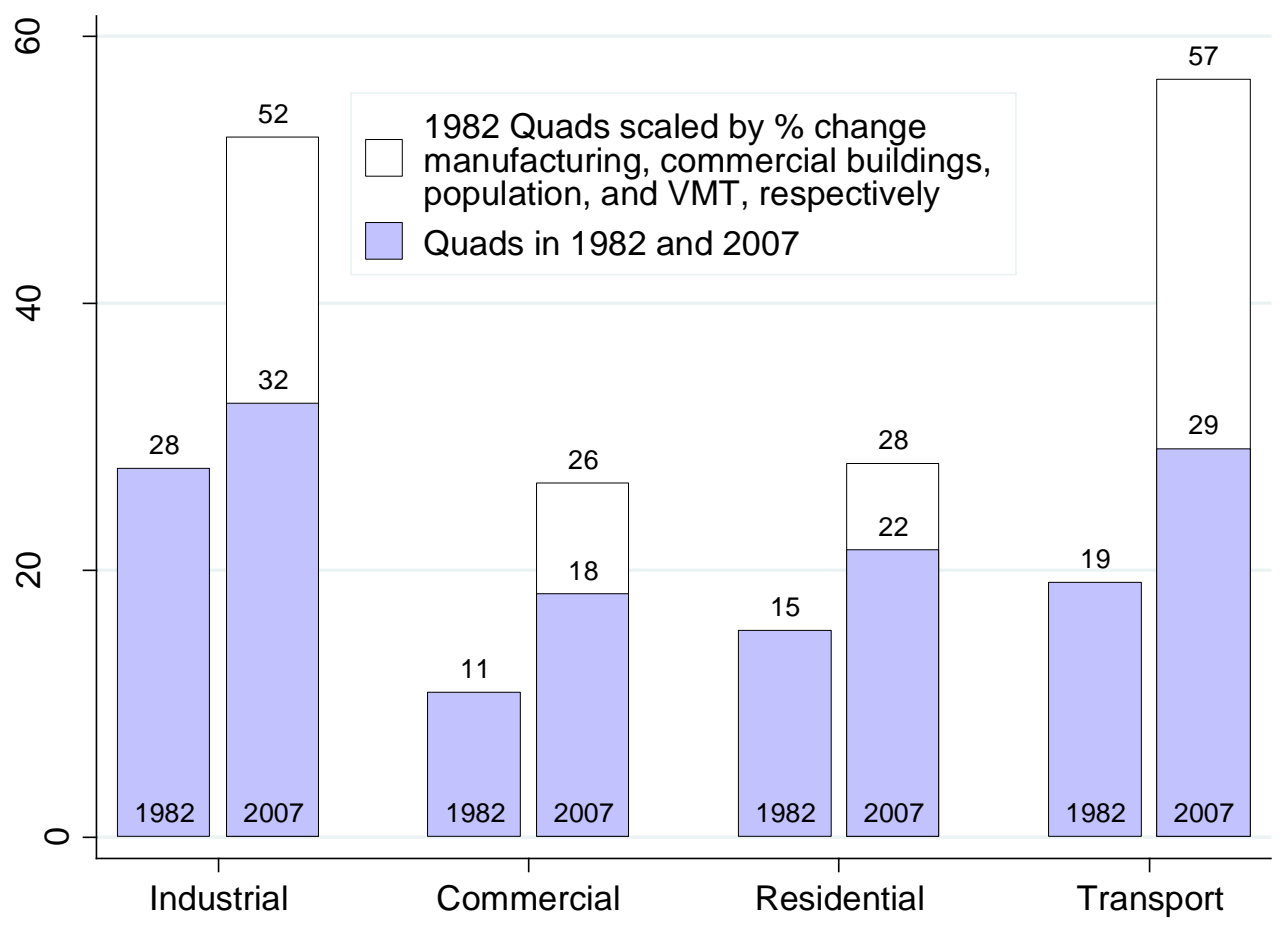


Figure 5. Scale and Deindustrialization Effects on Energy Intensity

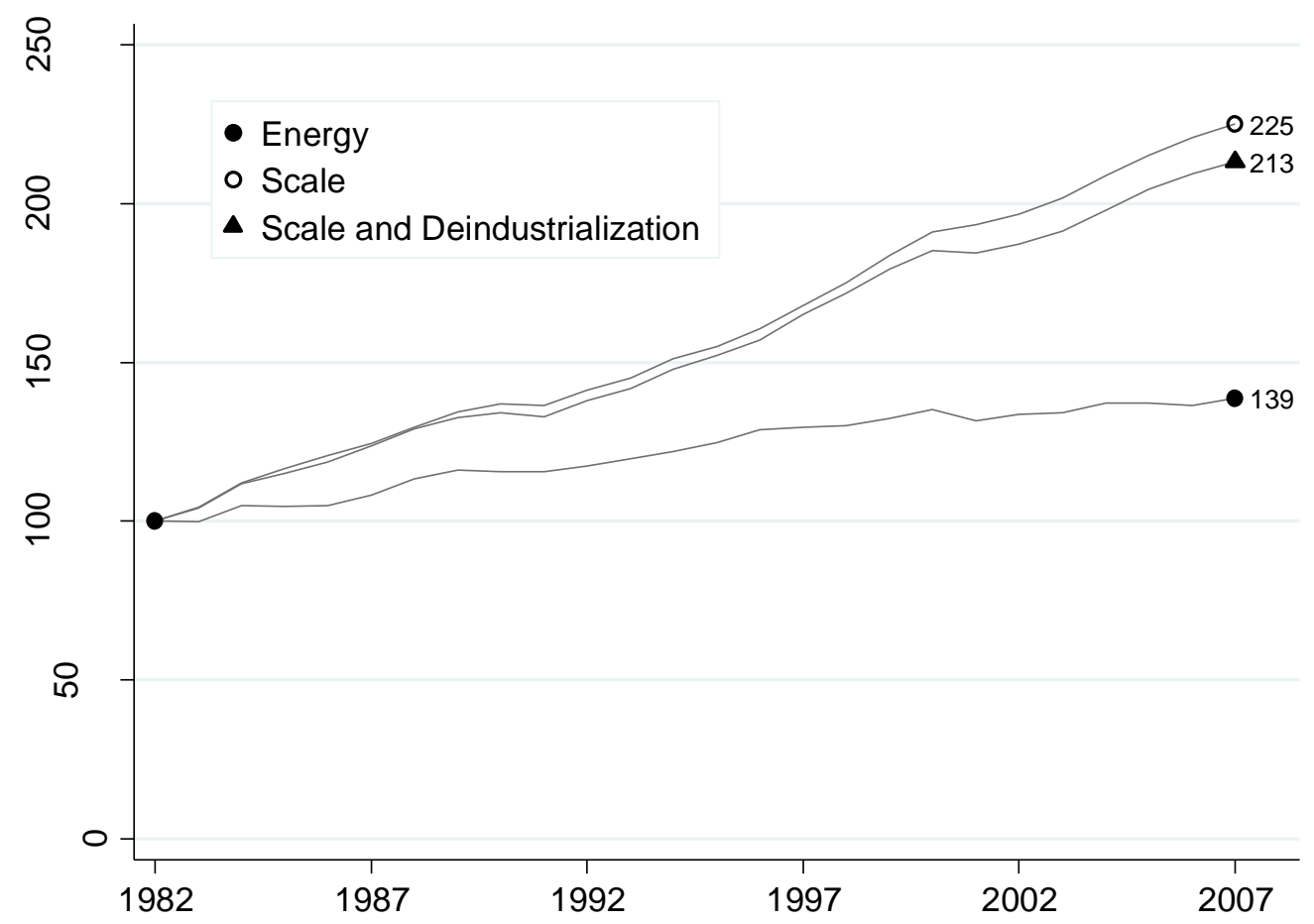

Figure 6. Deindustrialization and Decline in US Energy Intensity

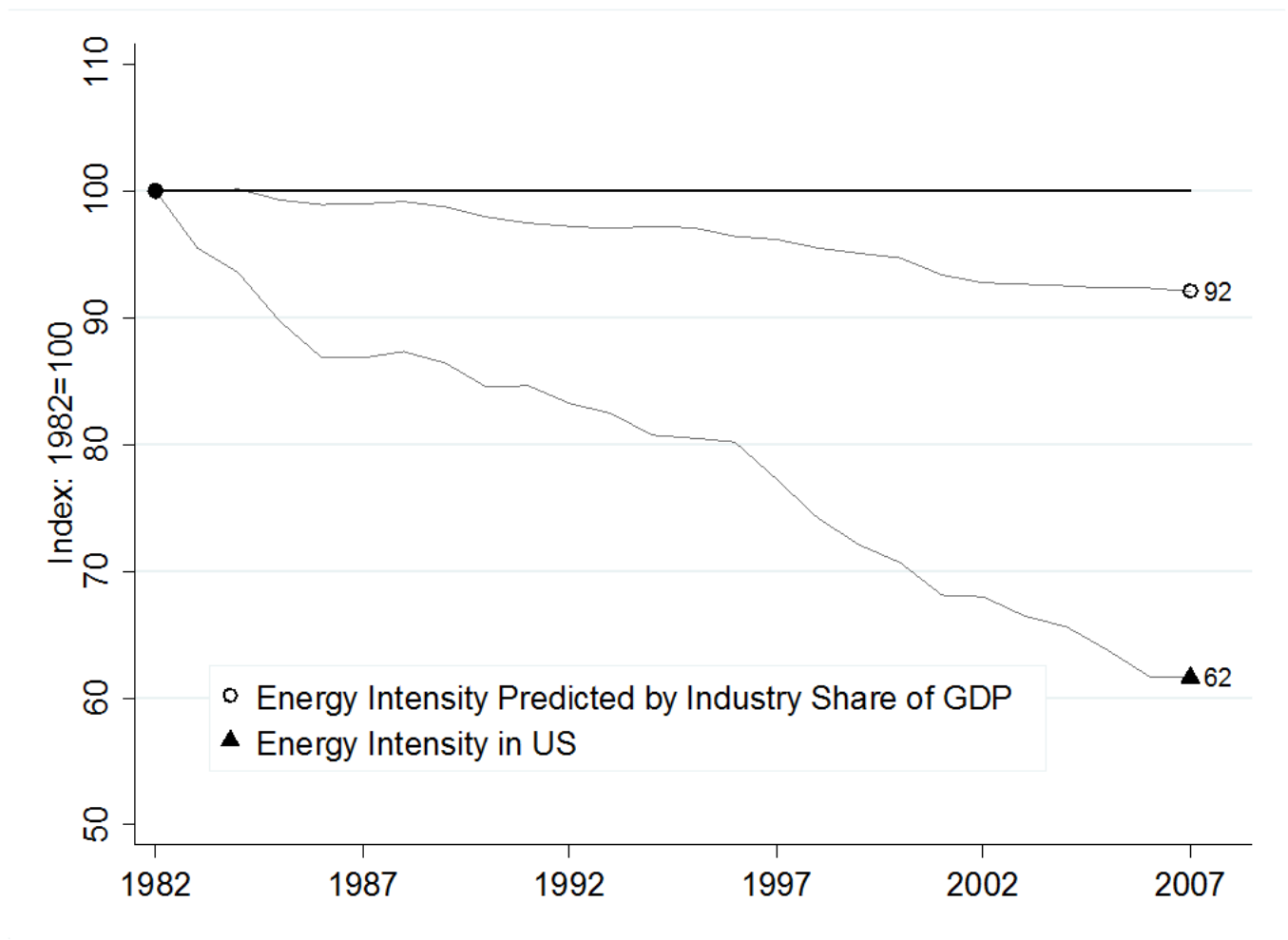


Figure 7. Changing Industry Shares and Energy Intensity, by State

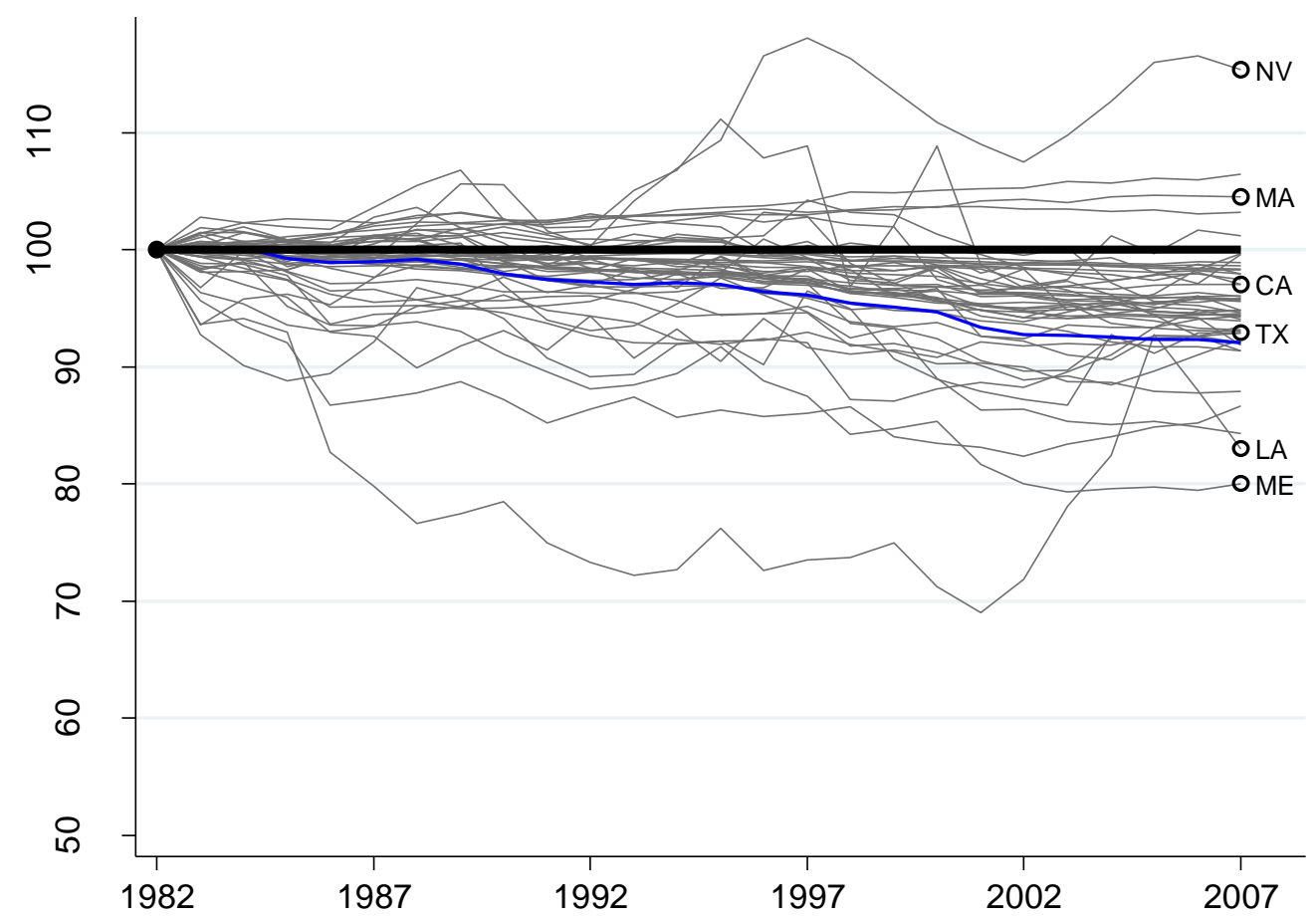

Figure 8. US States' Industrial Energy per Dollar of Output

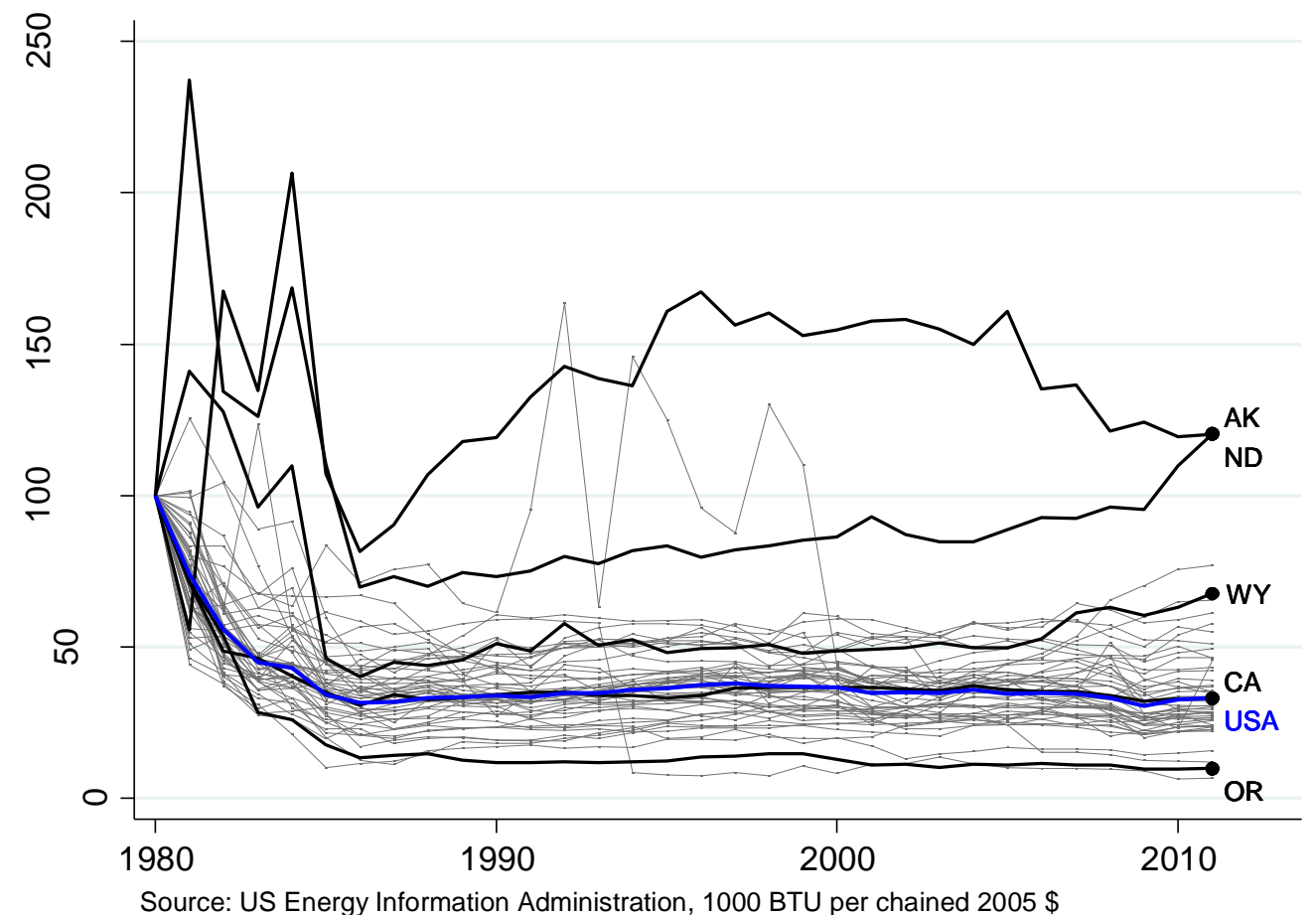


Figure 9. US States' Industrial Energy: Scale, Composition, Technique

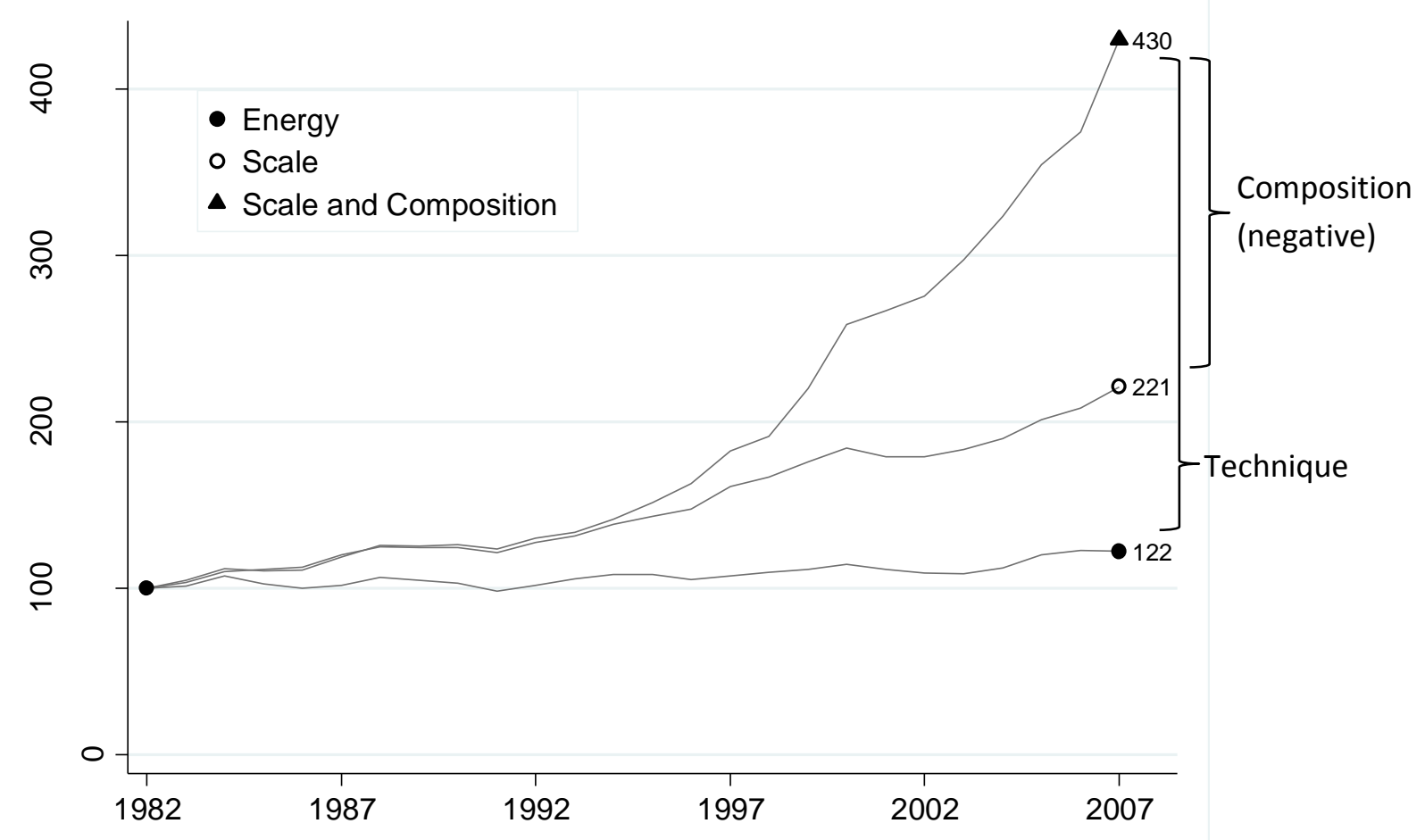

Figure 10. California Industrial Energy: Scale, Composition, Technique

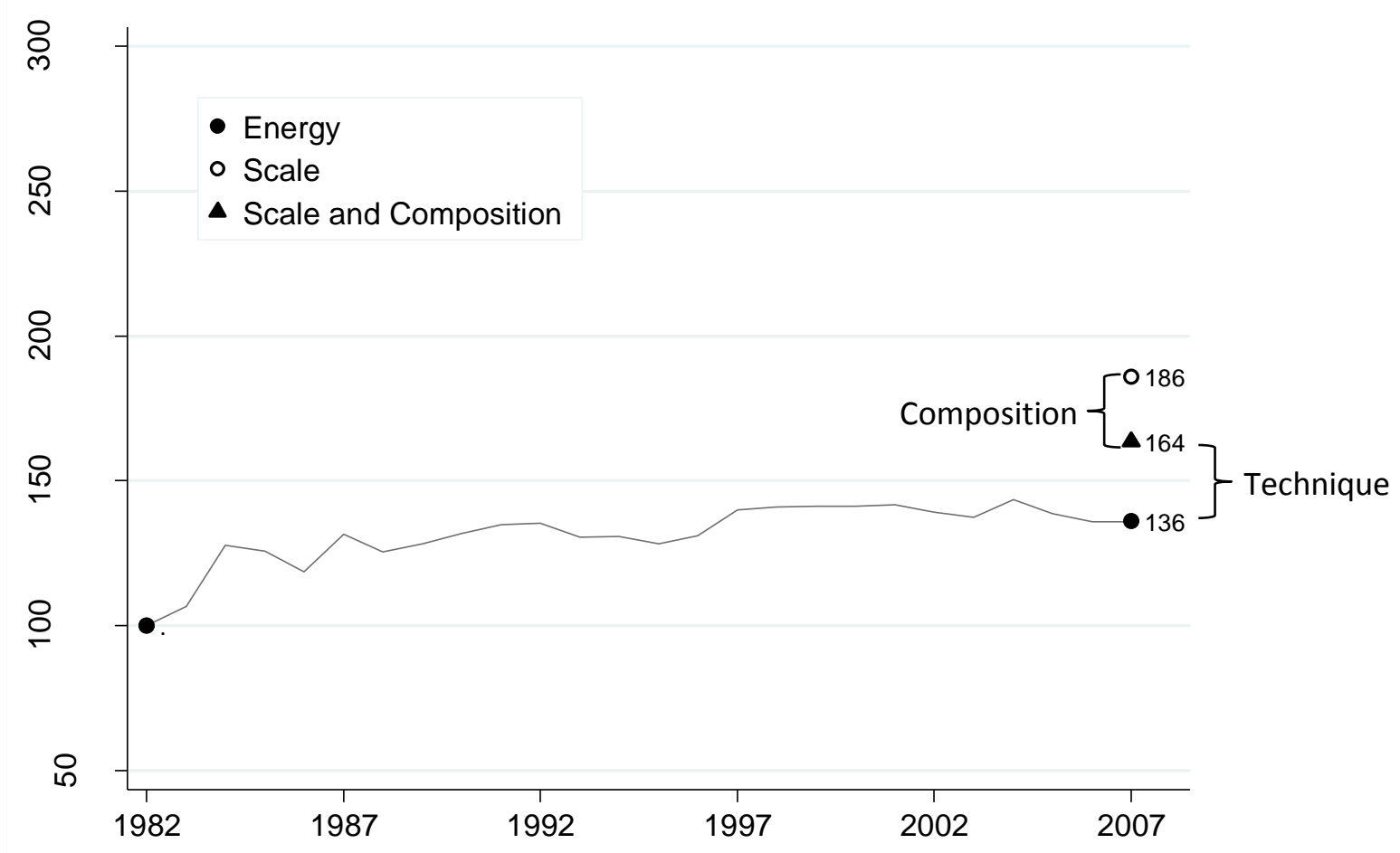


Figure 11. Texas Industrial Energy: Scale, Composition, Technique

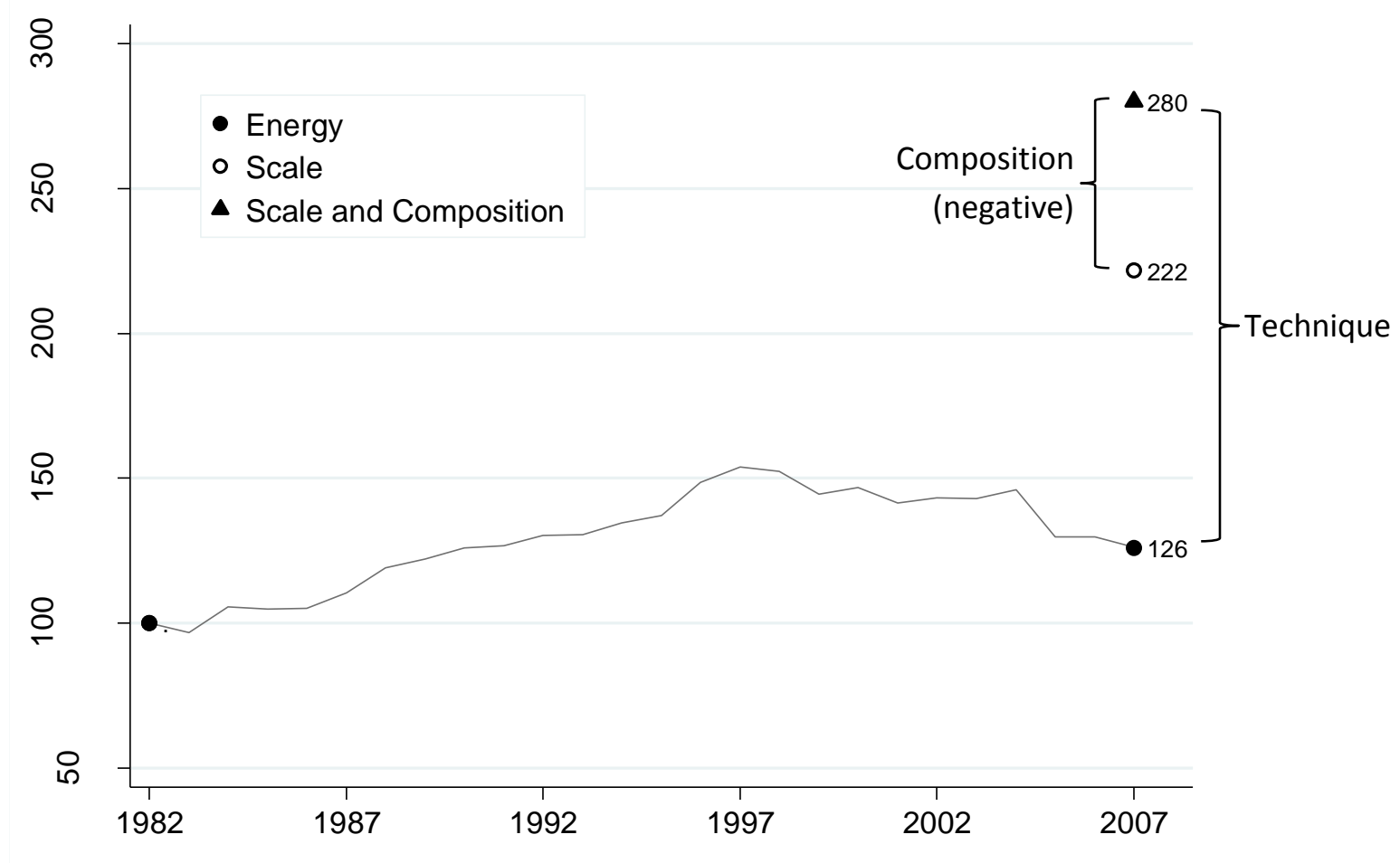


Appendix Table A1. Industrial Energy Changes in US States, 1982-2007

Economy-wide energy intensity

Percentage point Proportion due to decline in energy declining share of

\section{State}

(48 contiguous)

Alabama

Arizona

Arkansas

California

Colorado

Connecticut

Delaware

Florida

Georgia

Idaho

Illinois

Indiana

lowa

Kansas

Kentucky

Louisiana

Maine

Maryland

Massachusetts

Michigan

Minnesota

Mississippi

Missouri

Montana

Nebraska

Nevada

New Hampshire

New Jersey

New Mexico

New York

North Carolina

North Dakota

Ohio

Oklahoma

Oregon

Pennsylvania intensity industry in GDP

(1)

(2)

32.6

0.26

0.08

0.23

0.07

0.13

$-0.07$

0.14

0.07

0.19

0.13

0.15

0.01

0.10

0.01

0.37

0.88

0.44

0.31

$-0.10$

0.06

0.17

0.18

0.07

1.09

0.09

$-0.37$

0.00

0.03

0.13

0.11

0.03

$-0.63$

0.17

0.34

$-0.02$

0.24
Manufacturing energy changes

Energy

Growth Composition Technique

(3)

111

112

115

136

215

69

125

127

150

140

100

114

171

113

161

121

71

53

79

81

157

132

118

161

216

258

75

72

151

58

111

297

78

104

85

89

(4)

63

$-127$

92

22

7

$-3$

$-297$

25

54

10

3

115

24

8

31

34

33

$-28$

49

118

34

$-70$

$-13$

$-76$

$-41$

1055

108

11

12

12

$-7$

$-101$

13

$-9$

148

16
(5)

2

556

10

28

11

71

492

59

73

17

51

8

$-37$

39

125

$-2$

$-54$

160

47

121

96

117

42

293

$-20$

750

40

28

$-127$

45

49

538

72

69

78

28 


\begin{tabular}{lrrrrr} 
Rhode Island & 42.9 & -0.15 & 62 & 2 & 62 \\
South Carolina & 29.8 & 0.23 & 144 & -3 & 65 \\
South Dakota & 29.0 & 0.15 & 236 & -57 & -56 \\
Tennessee & 39.0 & 0.15 & 115 & 67 & 32 \\
Texas & 41.3 & 0.17 & 126 & -58 & 154 \\
Utah & 42.4 & 0.13 & 112 & 57 & 131 \\
Vermont & 42.1 & 0.05 & 77 & -16 & 102 \\
Virginia & 29.4 & 0.20 & 126 & 64 & 30 \\
Washington & 47.9 & 0.15 & 90 & 47 & 82 \\
West Virginia & 26.5 & 0.59 & 86 & 24 & 10 \\
Wisconsin & 35.3 & 0.11 & 99 & 18 & 112 \\
Wyoming & 17.0 & 0.30 & 131 & -12 & 51 \\
\hline
\end{tabular}

Sources: US Energy Information Administration, State Energy Data Systems (www.eia.gov/state/seds/seds-data-complete.cfm). US Census of Manufactures, 1982 and 2007. 
Appendix Table A2. Prices and Regulations in US States, 1982-2007

\begin{tabular}{|c|c|c|c|c|c|c|c|c|c|c|c|}
\hline \multirow[b]{2}{*}{ State } & \multicolumn{2}{|c|}{$\frac{\text { Prices, 1982- }}{\underline{2007}}$} & \multirow{2}{*}{$\begin{array}{l}\text { Year of } \\
\text { first } \\
\text { building } \\
\text { code }\end{array}$} & \multicolumn{2}{|c|}{ PACE index } & \multicolumn{2}{|c|}{$\frac{\text { Public spending }}{\underline{\text { shares }}}$} & \multirow{2}{*}{$\begin{array}{c}\text { Share of } \\
\text { population in } \\
\text { nonattainment } \\
\text { counties }\end{array}$} & \multicolumn{2}{|c|}{ Indexes } & \multirow{2}{*}{$\begin{array}{l}\text { Economic } \\
\text { growth } \\
\text { per } \\
\text { capita } \\
\end{array}$} \\
\hline & $\% \Delta$ & \$/MBTU & & Avg & $\Delta$ & Parks & Infrastruct & & ACEEE & LCV & \\
\hline & (1) & $(2)$ & (3) & (4) & (5) & $(6)$ & (7) & $(8)$ & (9) & $(10)$ & $(11)$ \\
\hline Alabama & 11.8 & 13 & 2005 & 1.19 & -0.25 & 0.013 & 0.097 & 0.21 & 2.0 & 21.1 & 172 \\
\hline Arizona & 16.3 & 16 & 2001 & 1.39 & -1.72 & 0.022 & 0.120 & 0.88 & 11.5 & 32.8 & 178 \\
\hline Arkansas & 32.0 & 13 & 1979 & 1.17 & 0.06 & 0.012 & 0.111 & 0.00 & 3.0 & 37.0 & 178 \\
\hline California & 37.8 & 23 & 1978 & 0.90 & 0.03 & 0.018 & 0.092 & 0.94 & 33.0 & 76.5 & 168 \\
\hline Colorado & 35.9 & 14 & 1978 & 1.01 & -0.25 & 0.029 & 0.127 & 0.66 & 15.5 & 55.9 & 166 \\
\hline Connecticut & 73.2 & 24 & 1999 & 0.67 & 0.32 & 0.015 & 0.104 & 1.00 & 33.0 & 81.6 & 200 \\
\hline Delaware & 47.6 & 15 & 1979 & 1.30 & -0.04 & 0.015 & 0.141 & 1.00 & 8.5 & 82.4 & 180 \\
\hline Florida & 38.1 & 16 & 1979 & 1.21 & -0.60 & 0.023 & 0.129 & 0.07 & 9.0 & 50.6 & 168 \\
\hline Georgia & 19.5 & 13 & 1978 & 0.91 & 0.04 & 0.015 & 0.113 & 0.51 & 6.0 & 22.4 & 180 \\
\hline Idaho & 70.9 & 9 & 2003 & 1.66 & -0.05 & 0.015 & 0.133 & 0.10 & 10.5 & 38.1 & 193 \\
\hline Illinois & 26.2 & 15 & - & 0.91 & 0.07 & 0.030 & 0.133 & 0.64 & 10.0 & 67.0 & 171 \\
\hline Indiana & 2.4 & 13 & 1979 & 1.14 & -0.16 & 0.018 & 0.102 & 0.45 & 5.0 & 29.9 & 176 \\
\hline lowa & 8.1 & 12 & 1978 & 0.96 & 0.05 & 0.018 & 0.135 & 0.00 & 16.5 & 54.2 & 188 \\
\hline Kansas & 5.5 & 14 & - & 0.76 & 0.09 & 0.014 & 0.129 & 0.00 & 7.0 & 14.7 & 162 \\
\hline Kentucky & 9.9 & 11 & 2005 & 0.99 & 0.13 & 0.014 & 0.117 & 0.29 & 6.5 & 24.6 & 161 \\
\hline Louisiana & 50.6 & 14 & 1999 & 1.51 & 0.31 & 0.018 & 0.112 & 0.13 & 5.5 & 27.5 & 139 \\
\hline Maine & 188.9 & 19 & 1980 & 1.55 & 0.41 & 0.010 & 0.119 & 0.00 & 15.5 & 58.8 & 168 \\
\hline Maryland & 95.3 & 15 & 1981 & 1.17 & -0.04 & 0.025 & 0.130 & 0.67 & 14.0 & 91.2 & 170 \\
\hline Massachusetts & 84.1 & 25 & 1975 & 0.67 & 0.19 & 0.013 & 0.129 & 1.00 & 29.0 & 72.4 & 204 \\
\hline Michigan & 14.8 & 16 & 1977 & 1.01 & -0.11 & 0.014 & 0.093 & 0.48 & 7.5 & 74.1 & 149 \\
\hline Minnesota & 17.8 & 13 & 1976 & 0.66 & 0.26 & 0.022 & 0.117 & 0.08 & 20.0 & 74.2 & 186 \\
\hline Mississippi & 11.1 & 14 & - & 1.47 & -0.33 & 0.010 & 0.109 & 0.00 & 1.0 & 35.3 & 173 \\
\hline Missouri & 7.2 & 13 & - & 0.79 & -0.02 & 0.018 & 0.126 & 0.29 & 2.0 & 30.4 & 160 \\
\hline Montana & 133.2 & 10 & 1972 & 1.49 & 0.46 & 0.011 & 0.134 & 0.52 & 13.0 & 26.5 & 138 \\
\hline
\end{tabular}




\begin{tabular}{|c|c|c|c|c|c|c|c|c|c|c|c|}
\hline Nebraska & 26.6 & 12 & 1980 & 0.83 & 0.09 & 0.013 & 0.104 & 0.00 & 6.5 & 11.8 & 181 \\
\hline Nevada & 78.9 & 16 & 1978 & 0.63 & 0.03 & 0.032 & 0.142 & 0.88 & 14.5 & 60.5 & 140 \\
\hline New Hampshire & 79.5 & 25 & 1977 & 0.75 & -0.08 & 0.013 & 0.115 & 0.73 & 14.5 & 70.6 & 219 \\
\hline New Jersey & 32.7 & 24 & 1977 & 0.82 & -0.33 & 0.018 & 0.126 & 1.00 & 22.0 & 83.5 & 187 \\
\hline New Mexico & -6.1 & 15 & 1978 & 1.64 & -1.41 & 0.021 & 0.132 & 0.00 & 11.0 & 85.5 & 170 \\
\hline New York & 55.4 & 18 & 1979 & 0.77 & 0.00 & 0.014 & 0.138 & 0.85 & 25.0 & 92.9 & 174 \\
\hline North Carolina & 34.3 & 14 & 1973 & 0.82 & -0.14 & 0.015 & 0.098 & 0.28 & 8.5 & 45.1 & 182 \\
\hline North Dakota & 5.7 & 14 & 1977 & 0.77 & -0.13 & 0.019 & 0.137 & 0.00 & 0.5 & 58.8 & 184 \\
\hline Ohio & 29.1 & 13 & 1979 & 0.82 & 0.16 & 0.015 & 0.102 & 0.67 & 9.5 & 58.1 & 164 \\
\hline Oklahoma & 30.1 & 12 & 1997 & 0.58 & -0.18 & 0.017 & 0.110 & 0.00 & 3.5 & 18.2 & 141 \\
\hline Oregon & 72.0 & 11 & 1974 & 1.22 & -0.12 & 0.017 & 0.118 & 0.11 & 28.0 & 83.0 & 212 \\
\hline Pennsylvania & 18.7 & 17 & 2004 & 0.91 & -0.07 & 0.010 & 0.119 & 0.71 & 16.0 & 70.7 & 167 \\
\hline Rhode Island & 56.4 & 25 & 1977 & 0.72 & 0.77 & 0.014 & 0.098 & 1.00 & 20.0 & 94.1 & 183 \\
\hline South Carolina & 24.0 & 12 & 1979 & 0.99 & -0.14 & 0.012 & 0.083 & 0.05 & 8.5 & 24.6 & 176 \\
\hline South Dakota & 15.1 & 13 & - & 0.68 & 0.55 & 0.023 & 0.163 & 0.00 & 1.5 & 56.0 & 220 \\
\hline Tennessee & 12.7 & 13 & 1978 & 1.10 & -0.03 & 0.015 & 0.097 & 0.22 & 4.0 & 29.9 & 179 \\
\hline Texas & 53.1 & 14 & 2000 & 1.39 & 0.22 & 0.014 & 0.118 & 0.51 & 17.5 & 19.4 & 153 \\
\hline Utah & 1.6 & 12 & 1976 & 0.93 & 0.08 & 0.021 & 0.116 & 0.83 & 9.5 & 21.8 & 170 \\
\hline Vermont & 65.9 & 21 & 1996 & 0.66 & 0.03 & 0.010 & 0.127 & 0.00 & 33.0 & 100.0 & 197 \\
\hline Virginia & 8.4 & 12 & 1974 & 0.96 & -0.03 & 0.019 & 0.139 & 0.21 & 6.0 & 60.4 & 179 \\
\hline Washington & 138.3 & 9 & 1978 & 1.37 & -0.19 & 0.020 & 0.122 & 0.12 & 27.0 & 80.1 & 157 \\
\hline West Virginia & 0.7 & 11 & 1989 & 1.58 & -0.27 & 0.012 & 0.123 & 0.40 & 6.5 & 58.1 & 155 \\
\hline Wisconsin & 38.1 & 13 & 1978 & 0.89 & 0.06 & 0.019 & 0.123 & 0.33 & 17.0 & 70.1 & 173 \\
\hline Wyoming & 28.8 & 10 & 1977 & 0.72 & 0.30 & 0.020 & 0.147 & 0.05 & 1.0 & 11.6 & 149 \\
\hline
\end{tabular}

Price data from Energy Information Administration http://www.eia.gov/state/seds/seds-data-complete.cfm; year of first building code from Aroonruengsawat et al. (2012); PACE indexes from Keller and Levinson (2002); public spending from Islam (2013); nonattainment share from US Environmental Protection Agency http://www3.epa.gov/airquality/greenbk/; ACEEE scorecard http://database.aceee.org/state-scorecard-rank; League of Conservation Voters http://scorecard.lcv.org/sites/scorecard.Icv.org/files/LCV_Scorecard_2010.pdf 